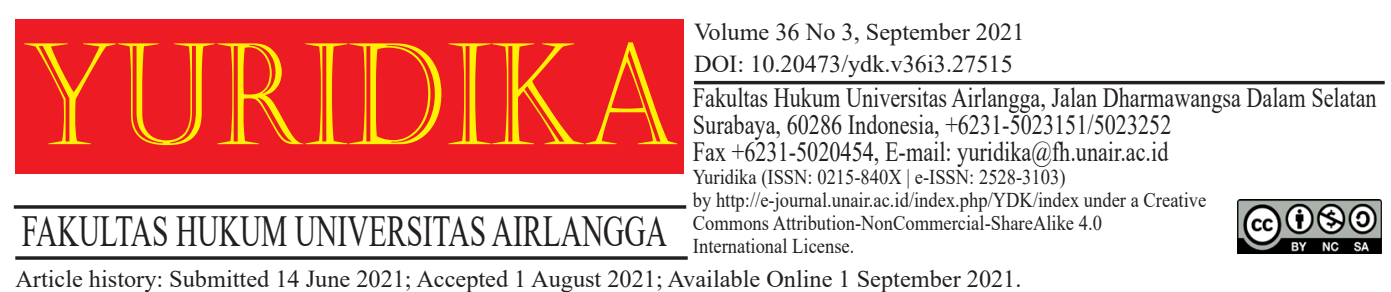

\title{
The Indonesian Government's Inconsistency in Handling the Covid-19 Pandemic
}

\author{
Syamsuddin Radjab and Muhammad Ikram Nur Fuady \\ ikram.nurfuady@uin-alauddin.ac.id \\ Universitas Islam Negeri Alauddin Makassar
}

\begin{abstract}
A clear legal framework is the basis of an effective policy, including when dealing with the Covid-19 pandemic. However, inconsistencies in this legal framework lead to legal uncertainty and public confusion. This research aims to critique the Indonesian government's approach to dealing with the Covid-19 pandemic, which began in early 2020, particularly the legal framework's inconsistency in enforcing different and ineffective legal sanctions at the central government and local government level. Normative research methods are used together with a statutory approach, while the research results are explained in a descriptive-qualitative way. This research shows that the government considers the Covid-19 pandemic a non-natural disaster and does not implement lockdowns. Meanwhile, the legal framework used is the health quarantine law, which requires implementing responses to public health emergencies very similar to lockdowns. In addition, the Large-Scale Social Restriction (PSBB) policy has its legal basis in a health quarantine law, while the Covid-19 pandemic situation is considered a non-natural disaster subject to the disaster management law. Furthermore, other results also show ineffective enforcement of legal sanctions, such as criminal sanctions in regional head decisions that cannot be enforced because the PSBB policy only includes administrative sanctions. In conclusion, the inconsistency of the legal framework in dealing with the Covid-19 pandemic is very detrimental to the community due to its impact on human rights, which can lead to legal uncertainty and public distrust of the government.
\end{abstract}

Keywords: Covid-19; Disaster; Disease Outbreak; Legal Framework Inconsistency.

\section{Introduction}

In the past, various virus or other disease outbreaks have been experienced by many people and countries, particularly the Black Death which was a communicable disease widespread in Europe and Asia. ${ }^{1}$ Malaria also had a large impact in Batavia,

'CJ Duncan and S Scott, "What Caused the Black Death?" (2005) 81 Postgraduate Medical Journal.[315]. 
which at the time in the seventeenth century was still a Dutch colony. ${ }^{2}$ Therefore, seen in a historical context, disease outbreaks are not new, even if individual outbreaks are different. All transmissible diseases can only be resisted by the knowledge of science, not with shamans or talismans which are traditional customs among the Bugis, Makassar and other tribes. ${ }^{3}$

In the Covid-19 context, data from the World Health Organization (WHO) categorises the stages of an outbreak of transmissible diseases on a scale from sporadic to pandemic according to the number of patients, the extent of the area and the escalation of transmission. The total number of confirmed cases is $172,630,637$ with total deaths at 3,718,683. ${ }^{4}$ The outbreak and early development of the Covid-19 global pandemic was observed on the 30th December, 2019 at Junyintan Hospital in Wuhan, China. Patients were affected by a disease which became known as Covid-19, and the disease quickly spread to several provinces in China. ${ }^{5}$

In a period of two months, the outbreak spread to Europe and America as well as the continents of Asia and Africa. ${ }^{6}$ Then on the 11th of March 2020, WHO announced that the Covid-19 outbreak was categorized as a pandemic (meaning the highest stage of danger for a communicable disease), and a week later on the 17th of March 2020, in Indonesia President Jokowi announced that Covid-19 was a national non-natural disaster. ${ }^{7}$

${ }^{2}$ PH van der Brug, "Malaria in Batavia in the 18th Century." (1997) 2 Tropical medicine \& international health : TM \& IH.[892].

${ }^{3}$ Ayu Setyoningsih and Myrtati D Artaria, "Pemilihan Penyembuhan Penyakit Melalui Pengobatan Tradisional Non Medis Atau Medis" (2016) 29 Masyarakat, Kebudayaan dan Politik.[46].

${ }^{4}$ Numbers at a Glance, "Coronavirus Disease (COVID-19) Pandemic" (WHO, 2021) $<$ https://www.who.int/emergencies/diseases/novel-coronavirus-2019?gclid=Cj0KCQjw5PGFBhC2ARIsAIFIMNcZSJK83O40W2ii6I-Qr8hWWEbo3WH_AYJsYDbKSBhVaaiBpkRF-xIaArlsEALw wcB $>$ accesed 10 June 2021.

${ }^{5}$ Yujun Wei, [et., al], "COVID-19 Prevention and Control in China: Grid Governance" (2021) 43 Journal of Public Health.[76].

${ }^{6}$ Adekunle Sanyaolu, [et.,al], "Global Pandemicity of COVID-19: Situation Report as of June 9, 2020" (2021) 14 Infectious Diseases: Research and Treatment.[1178633721991260].China in December 2019. This cluster quickly spread across the globe and led the World Health Organization (WHO).

${ }^{7}$ Riyanti Djalante and others, "Review and Analysis of Current Responses to COVID-19 in Indonesia: Period of January to March 2020" (2020) 6 Progress in Disaster Science.[100091]. 
As a non-natural disaster, the Indonesian government established a Covid-19 Eradication Task Force (Satgas) in March 2020, which was led by the chairman of the National Disaster Management Agency (BPBN), namely a Lieutenant General of TNI, Moni Monardo. ${ }^{8}$ Then, Covid-19 was designated a non-natural disaster based on Law no. 24 of 2007 concerning Disaster Management. ${ }^{9}$

Indonesia's response to Covid-19 contrasts with those of other countries. China implemented a lockdown in several areas such as Wuhan City by isolating the population in their homes and forbidding them without exception from undertaking activities outside the home. ${ }^{10}$ The United States also implemented a lockdown in twenty-three states during the beginning of the Covid-19 pandemic. ${ }^{11}$ Likewise, neighboring countries, such as Malaysia, also implemented a one-month lockdown in early $2020 .^{12}$

These countries consider the Covid-19 pandemic to be a disease outbreak that must be controlled by breaking the chain of transmission with lockdowns. Although the decision to lock down generally causes an economic recession, it is a temporary impact. ${ }^{13}$ Meanwhile, during the lockdown period, the relevant government provided assistance to its citizens by directly distributing aid in the form of food and life necessities to each of its citizens' homes. ${ }^{14}$ This is a clear example of states

${ }^{8}$ Fitri Haryanti Harsono, "Kiprah Doni Monardo Saat Menjabat Kepala BNPB Dan Jadi Ketua Satgas COVID-19” (liputan6.com, 2021) < https:/www.liputan6.com/health/read/4565825/ kiprah-doni-monardo-saat-menjabat-kepala-bnpb-dan-jadi-ketua-satgas-covid-19> accesed 6 June 2021.

9 Undang-Undang Republik Indonesia Nomor 24 Tahun 2007 Tentang Penanggulangan Bencana 2007.

${ }^{10}$ Venus Khim-Sen Liew, "Impact Of Wuhan Lockdown In Early Stage Of Covid-19 Outbreak On Sector Returns In Chinese Stock Market” (2021) 56 Journal Of Southwest Jiaotong University.[524].

${ }^{11}$ Jacob Gershman, "A Guide to State Coronavirus Reopenings and Lockdowns" (The Wall Street Journal, 2020) <https://www.wsj.com/articles/a-state-by-state-guide-to-coronavirus-lockdowns-11584749351> accesed 14 June 2021.

${ }^{12}$ Vimala Balakrishnan, Azmawaty Mohamad Nor and Nor Zuraida Zainal, "COVID-19 Nationwide Lockdown and It's Emotional Stressors among Malaysian Women” (2021) 10 Asia Pacific Journal of Social Work and Development.[14] .

${ }^{13}$ Dea Rosa Gracia and Erica Rosa Rubetta, "Literature Review: Quarantine and Lockdown During Covid19 Outbreak Impact on Mental Health Problem" (2020) 12 Jurnal Kesehatan Lingkungan.[29].

${ }^{14}$ Annissa Rezki Nur Rohim Yunus, "Kebijakan Pemberlakuan Lock Down Sebagai Antisipasi Penyebaran Corona Virus Covid-19” (2020) 7 SALAM: Jurnal Sosial dan Budaya Syar-i.[227]. 
meeting their responsibility to maintain the basic human right to survive, including during the Covid-19 pandemic. ${ }^{15}$

Instead of implementing lockdowns, the Indonesian government employed other measures. Since March 2020, the government has imposed Large-Scale Social Restrictions (PSBB) in several areas. ${ }^{16}$ This policy differs from lockdowns in that people's mobility is maintained, even though it is limited to movement to meet basic needs and obtaining medicines. In addition, during the PSBB policy, the government did not provide assistance to the community despite the negative economic impact of the Covid-19 period which led to the community suffering greatly. ${ }^{17}$

On the other hand, some parties argued that the Covid-19 pandemic should be considered a disease outbreak as designated by WHO. If the government officially announces that the Covid-19 pandemic is a disease outbreak, then it must implement health quarantine measures. ${ }^{18}$ This quarantine is in principle the same as the lockdown policy, which already has a legal framework, namely Law Number 6 of 2008 concerning Health Quarantine jo. Decree of the Minister of Health of the Republic of Indonesia Number 612/MENKES/SK/V/2010 concerning Guidelines for the Implementation of Health Quarantine in Handling Public Health Emergencies Troubling the World. ${ }^{19}$ Under this law, the government would be obliged to assist citizens with health quarantine to avoid the Covid-19 outbreak.

As the Indonesian government chose to designate the Covid-19 pandemic as a non-natural disaster, many citizens suffered. As a result, the human rights of the

${ }^{15}$ Omar F Alotain Maysa S Bydoon, "State Responsibility and COVID 19” (2019) 08 Journal of Arts \& Humanities.[17].

${ }^{16}$ L1 Irman Suhaedading, "Pembatasan Sosial Berskala Besar (PSSB) Saat Pandemi Covid-19 Dan Dampaknya Bagi Pasar Modal Indonesia" (2020) 2 Abiwara: Jurnal Vokasi Administrasi Bisnis.[33].a month before PSBB (2 March 2020 - 9 April 2020).

${ }^{17}$ ibid.[35].a month before PSBB (2 March 2020 - 9 April 2020).

${ }^{18}$ Rela Rizki Pratiwi, Hasrina Nurlaily and Demi Artha, "Analisa Yuridis Penetapan Covid 19 Sebagai Kedaruratan Kesehatan Masyarakat Ditinjau Dari Peraturan Perundang-Undangan Di Indonesia" (2020) 1 Journal Inicio Legis.[12].

${ }^{19}$ Keputusan Menteri Kesehatan Republik Indonesia Nomor 612/MENKES/SK/V/2010 Tahun 2010 tentang Pedoman Penyelenggaraan Karantina Kesheatan pada Penanggulangan Kedaruratan Kesehatan Masyarakat yang Meresahkan Dunia. 
community were violated due to the PSBB policy. ${ }^{20}$ This designation led to PSBB implementation without any assistance from the government as mandated by the Universal Declaration of Human Rights, which has been ratified in Law Number 39 of 1999 concerning Human Rights. ${ }^{21}$ As a result, many people remain trapped in debt, their businesses have gone bankrupt, and they continue to have difficulty surviving due to economic uncertainty. ${ }^{22}$

The government's inconsistent position led to this community suffering in dealing with Covid-19. The source of this problem was a legal framework that did not match the Indonesian government's assumption that Covid-19 was a nonnatural disaster. At the same time, the PSBB is based on the Law on Outbreaks of Diseases, which obliges the government to declare a public health emergency and implement a lockdown.

It is hoped that the research results and criticism in this paper will assist policymakers so that the human rights of every citizen can be maintained during the Covid-19 period. Therefore, it is important to critique the policies taken by the government. This critique can be in the form of questions, namely:

1. What are the legal inconsistencies in handling the Covid-19 pandemic?

2. How are legal sanctions enforced during the Covid-19 pandemic in Indonesia?

This study takes the form of normative research with a statutory and critical review approach. ${ }^{23}$ The research results will be explained descriptively-qualitatively by examining various regulations and facts related to the Covid-19 period in Indonesia from March 2020 to May 2021. ${ }^{24}$

\footnotetext{
${ }^{20}$ A Widyawati and others, "Covid-19 and Human Rights: The Capture of the Fulfilment of Rights During the Covid Outbreaks” (2020) 6 Unnes Law Journal.[259].

${ }^{21}$ Undang-Undang Republik Indonesia Nomor 39 Tahun 1999 Tentang Hak Asasi Manusia 1999.

${ }^{22}$ Abitassha Az Zahra Nano Prawoto, Eko Priyo Purnomo, "The Impacts of Covid-19 Pandemic on Socio-Economic Mobility in Indonesia" (2020) VIII International Journal of Economics and Business Administration.[57].

${ }^{23}$ Brenda Marshall, [et.,al], Qualitative, Quantitative, and Mixed Methods Research Designs (Fifth Edit, SAGE Publications Inc 2018).[214].

${ }^{24}$ W Lawrence Neuman, Social Research Methods: Qualitative and Quantitative Approaches, vol 30 (Seventh Ed, Pearson Custom Library 2002).[76].
} 


\section{Inconsistency in Handling the Covid-19 Pandemic}

In the context of international human rights instruments, the International Covenant on Civil and Political Rights (ICCPR) focuses on civil and political rights and emphasises the right using the wording "right to/of ", such as the right to life, freedom of association, and others. These are also often referred to as "negative rights" in the sense of the fulfillment of rights. If the state is absent or does not actively interfere with the rights in question, protection and respect is provided, as is explained in Article 1 Paragraph (3) of the ICCPR. ${ }^{25}$

On the other hand, with regard to economic, social and cultural rights, the state must be actively involved in them because their fulfillment is closely related to the activeness of the state in carrying out its obligations. The right to health or freedom from Covid-19 virus can only be perceived and fulfilled if the state is present therein. Without active state involvement, Covid-19 will be difficult to overcome and control.

Therefore, there is a strong relationship between human rights and the state. When the theory and concepts of the rights of humans are adopted, they enter into the constitution of the country, even in a totalitarian state. Rights as human beings and creatures of God with freedom and the right to life when incorporated into the constitution become an obligation of the state, not only in the application of the country's constitution, but also as an instrument of international treaties the state has signed.

Since Covid-19 entered Indonesia in February 2020, government officials have made many comments about Covid-19 that are unproductive and over-simplified. They have also been hesitant in determining the status of laws related to Covid-19, first assigning it the status of a civilian emergency, then a health emergency and finally a non-natural national disaster emergency. Determination of its status is very important for seeing the pandemic in objective and realistic terms that result in laws on activity, management, finance and responsibility of the state as well as the enforcement of the law.

${ }^{25}$ International Covenant on Civil and Political Rights (ICCPR) 1976. 
The Indonesian government decided to designate the Covid-19 outbreak as a non-natural disaster. Furthermore, the government assisted the Covid-19 Task Force led by the National Disaster Management Agency (BNPB) in March 2020. However, such a state or government has taken some significant steps in the prevention and control of Covid-19 to formulate a health protocol that emphasises the "3M" (wear masks, wash hands and keep distance). In fact, this was expanded to the term "5M" with two more rules (stay away from crowds, limit mobility).

The following are forms of inconsistency that occurred during the Covid-19 pandemic in Indonesia:

1. Inconsistency of the Legal framework applied:

Indonesia's government designated Covid-19 as a non-natural disaster through Law No 24 of 2007 concerning Disaster Management. This led the government to form a Covid-19 Task Force led by the head of the National Disaster Management Agency (BNPB) in March 2020, guided by Law Number 24 of 2007 concerning Disaster Management. However, in its implementation, the government issued a policy through presidential decree number 21 of 2020 regarding Large-Scale Social Restrictions (PSBB) based on Law No. 4 of 1984 on Infectious Disease outbreaks and Law No 6 of 2018 on Health Quarantine.

As a state of law, it is crucial to have a legal framework as the basis of all policies. For example, if the government stipulates that the Covid-19 pandemic is a non-natural disaster, then it is appropriate to base its response on Law Number 24 of 2007 concerning Disaster Management led by the chairman of BNPB. Meanwhile, according to researchers, the PSBB policy is based on Law No. 4 of 1984 concerning Infectious Disease outbreaks jo., whereas Law No 6 of 2018 concerning Health Quarantine can be applied as lockdowns if the government determines the Covid-19 pandemic is an infectious disease outbreak and global health emergency.

In July 2020, the Covid-19 task force was reconfigured as a Covid-19 Handling Committee consisting of the Policy Committee, Chief Executive, 
and Task Force through Presidential Decree No. 82 of $2020 .{ }^{26}$ However, again, researchers saw no firmness from the government in responding to the Covid-19 suppression because this committee only focuses on economic recovery without consideration of the legal framework.

In addition, responsible institutions need to submit to the National Agency for Combating Disasters (PNPB) according to the established legal framework. However, the implementation also frequently changes and there were at least three changes to what is now called the "Committee", which in addition to managing Covid-19 must also manage the recovery of the economy. These are two conflicting interests: controls to suppress Covid-19 require prohibitions on people's movements, while the economy requires high mobility to promote economic activity.

2. Conflict in Policymaking:

The Ministry of Health is the authorized institution in a disease outbreak such as the Covid-19 pandemic. Therefore, the 5M rules and health protocols are basic tasks carried out by the Ministry of Health, while other departments should have supporting roles only. However, the government's approach in forming a Covid-19 Handling Committee seems to focus on economic recovery and marginalizes the interests of public health. As a result, the Minister of Health is not able to act because other ministers, particularly those with responsibility for the economy, insist that wheels of the economy keep turning and activity in all industry sectors continues, however limited.

Furthermore, there are policy conflicts between the central and regional governments. The local governments favour a lockdown policy while the central government does not. The regional governments are more focused on preventing the spread of the coronavirus by implementing a lockdown. The local governments consider lockdowns a solution as they have been

\footnotetext{
${ }^{26}$ Anonim, "Pemerintah Bentuk Komite Penanganan Covid-19 Dan Pemulihan Ekonomi Nasional" (ekon.go.id, 2020) <https://ekon.go.id/info-sektoral/17/96/berita-pemerintah-bentukkomite-penanganan-covid-19-dan-pemulihan-ekonomi-nasional> accesed 10 June 2021.
} 
implemented in other countries, such as China and Malaysia. Meanwhile, the central government does not want to lock down because the economy will be paralysed. This illustrates that central government policies are directed more towards the economy than public health.

The Tourism Ministry provides another example of contradictory policy. Tourist attractions were opened to visitors within a short distance, as stated in the 2021 Covid-19 Handling Task Force Circular. ${ }^{27}$ This policy deliberately invites crowds of people who become new agents of Covid-19 transmission, even though they are from the local area. On the other hand, the government implemented restrictions on the mobility of domestic travelers (PPDN), which resulted in prohibitions on people returning to their hometowns. ${ }^{28}$

These conflicting policies were the consequence of the inconsistent legal framework. At the implementation stage, there is legal uncertainty. In the end, people become victims of these policies by losing the right to travel home, the right to worship and other limitations. This situation could be avoided if the government firmly considers that the Covid-19 pandemic is an infectious disease outbreak, not a non-natural disaster.

\section{Enforcement of Sanctions during the Covid-19 Pandemic}

In the Covid-19 context, using the Law of Disaster Act to manage outbreaks of disease and quarantine health affects the fulfillment of the human rights of people amid disasters. It is mainly the responsibility of the state to replace the losses of citizens in countries affected by Covid-19, which may be a result of negligence or not anticipated by the state in dealing with disease outbreaks.

Sanctions in the implementation of PSBB in the Health Quarantine Law are administrative sanctions, not criminal sanctions. Although the Law on Quarantine

\footnotetext{
${ }^{27}$ Jawahir Gustav Rizal, "Mudik Dilarang Tapi Tempat Wisata Dibuka, Ini Penjelasan Satgas Penanganan Covid-19" (Kompas.com, 2021) <https://www.kompas.com/tren/ $\mathrm{read} / 2021 / 04 / 23 / 201000865 /$ mudik-dilarang-tapi-tempat-wisata-dibuka-ini-penjelasan-satgaspenanganan?page=all $>$ accesed 11 June 2021 .

${ }^{28}$ ibid.
} 
regulates crimes, it is intended more for those who deliberately fight against the enactment of this law, especially the lockdown policy, by imposing fines in the province of Jakarta, social work sanctions or revocation of business licenses.

There are several sanctions regarding the implementation of PSBB both in government regulations and in the following Presidential Instruction. In the Presidential Instruction related to the enforcement of the Covid-19 Law, it is clear that the sanctions consist of:

1. Verbal or written warnings;

2. Social work;

3. Administrative fines; or

4. Suspension or temporary closure of business operations.

We agree that the regulations under the law must not have criminal provisions, as Professor Andi Hamzah has also argued. ${ }^{29}$ When there are criminal provisions, there will be legal uncertainty because the reference for criminal sanctions is the Criminal Code (KUHP) and equivalent laws. As a result, it can be seen that regulations such as the Decree of the Governor of Jakarta Number 107 of 2021 concerning Restrictions on Micro-Based Community Activities (PPKM) are ineffective because they have criminal provisions but cannot be enforced. ${ }^{30}$

There are similar regulations in other regions such as the Makassar Mayor Regulation Number 22 of 2020 concerning the Implementation of Large-Scale Social Restrictions (PSBB) in Makassar City, which has criminal sanctions. ${ }^{31}$ This regulation states that PSBB has criminal sanctions that Satpol PP will enforce following applicable regulations. The statement is very contradictory because if we examine the basis for this PSBB in Presidential Regulation No. 21 of 2020, then the legal framework is the Infectious Disease Outbreak Law. However, the government is adamant it will not implement public health emergency measures, such as lockdowns.

\footnotetext{
${ }^{29}$ Andi Hamzah, Hukum Acara Pidana Indonesia (Edisi kedu, Sinar Grafika 2019).[89].

${ }^{30}$ Keputusan Gubernur Jakarta Nomor 107 Tahun 2021 tentang Pembatasan Kegiatan Masyarakat Berbasis Mikro (PPKM).

${ }^{31}$ Peraturan Walikota Makassar Nomor 22 Tahun 2020 Tentang Pelaksanaan Pembatasan Sosial Berskala Besar (PSBB) Di Kota Makassar Provinsi Sulawesi Selatan.
} 
On the other hand, designating Covid-19 as a state emergency in the form of a disaster emergency is the weakness of this regulation which can result in government taking actions in the name of emergencies that are contrary to democratic values and human rights. For example, the legal immunity for state administrators in the 1998 crisis in financial sector policies led to much corruption in the BLBI case. ${ }^{32}$

This was related to policies between departments and central and regional governments or between provinces and districts or cities. The determination of sanctions was unclear as administrative sanctions were applied to criminal acts that were not under the stipulated regulations.

\section{Conclusion}

The Covid-19 pandemic is an emergency that must be managed appropriately. Proper management must be subject to a legal framework that is applied consistently so that the implementation phase will be effective and efficient. However, the assumption of the Indonesian government that the Covid-19 pandemic is a nonnatural disaster using the legal basis of the Health Quarantine Law is inappropriate in the circumstances. As a result, many people's human rights are restricted due to the PSBB, PPKM, PPDN policies and the prohibition on travelling home. On the other hand, the government allows economic activities to continue, such as the opening of tourist attractions which have the potential to worsen the situation.

The determination that Covid-19 is a non-natural national disaster is not relevant since an infectious disease outbreak should be considered under Law Number 4 of 1984 and Law Number 6 of 2018 concerning health quarantine. With the status of "Emergency State," it is necessary to observe and discuss the possible birth of "Constitutional Authoritarianism" under the pretext of an emergency which destroys the order of democratic values and human rights. The application of

${ }^{32}$ Muhammad Idris, "Perjalanan Kasus BLBI Sjamsul Nursalim Yang Rugikan Negara Rp 4,5 Triliun" (money.kompas.com, 2021) <https://money.kompas.com/read/2021/04/09/071630926/ perjalanan-kasus-blbi-sjamsul-nursalim-yang-rugikan-negara-rp-45-triliun?page=all $>$ accesed 13 June 2021. 
Article norms that do not refer to the legal framework "Disaster" but uses Articles in the Health Quarantine Law is not the primary reference. Therefore, this research suggests that governments in every country develop appropriate and consistent policies from the start so that implementing regulations and enforcing legal sanctions can be carried out optimally.

\section{Bibliography}

Anonim, "Pemerintah Bentuk Komite Penanganan Covid-19 Dan Pemulihan Ekonomi Nasional" (ekon.go.id, 2020) <https://ekon.go.id/infosektoral/17/96/berita-pemerintah-bentuk-komite-penanganan-covid-19-danpemulihan-ekonomi-nasional $>$.

Balakrishnan V, Mohamad Nor A and Zainal NZ, "COVID-19 Nationwide Lockdown and It's Emotional Stressors among Malaysian Women" (2021) 15 Asia Pacific Journal of Social Work and Development $1<$ https://doi.org/1 0.1080/02185385.2021.1886976>.

Djalante R and others, "Review and Analysis of Current Responses to COVID-19 in Indonesia: Period of January to March 2020" (2020) 6 Progress in Disaster Science $100091<\mathrm{https} / /$ www.sciencedirect.com/science/article/pii/ S2590061720300284>.

Duncan CJ and Scott S, "What Caused the Black Death?" (2005) 81 Postgraduate Medical Journal.

Gershman J, "A Guide to State Coronavirus Reopenings and Lockdowns" (The Wall Street Journal, 2020) <https://www.wsj.com/articles/a-state-by-stateguide-to-coronavirus-lockdowns-11584749351>.

Glance N at a, "Coronavirus Disease (COVID-19) Pandemic" (WHO, 2021) $<$ https:// www.who.int/emergencies/diseases/novel-coronavirus-2019?gclid=Cj0K CQjw5PGFBhC2ARIsAIFIMNcZSJK83O40W2ii6I-Qr8hWWEbo3WH_ AYJsYDbKSBhVaaiBpkRF-xIaArlsEALw_wcB>.

Gracia DR and Rubetta ER, "Literature Review: Quarantine and Lockdown During Covid19 Outbreak Impact on Mental Health Problem" (2020) 12 Jurnal Kesehatan Lingkungan.

Hamzah A, Hukum Acara Pidana Indonesia (Edisi kedua, Sinar Grafika 2019).

Harsono FH, "Kiprah Doni Monardo Saat Menjabat Kepala BNPB Dan Jadi Ketua 
Satgas COVID-19" (liputan6.com, 2021) <https://www.liputan6.com/health/ $\mathrm{read} / 4565825 /$ kiprah-doni-monardo-saat-menjabat-kepala-bnpb-dan-jadiketua-satgas-covid-19>.

Idris M, "Perjalanan Kasus BLBI Sjamsul Nursalim Yang Rugikan Negara Rp 4,5 Triliun” (money.kompas.com, 2021) <https://money.kompas.com/ $\mathrm{read} / 2021 / 04 / 09 / 071630926 /$ perjalanan-kasus-blbi-sjamsul-nursalim-yangrugikan-negara-rp-45-triliun?page $=$ all $>$.

Liew VK-S, "Impact Of Wuhan Lockdown In Early Stage Of Covid-19 Outbreak On Sector Returns In Chinese Stock Market” (2021) 56 Journal Of Southwest Jiaotong University.

Marshall B, Heinzen T and Roberts K, Qualitative, Quantitative, and Mixed Methods Research Designs (Fifth Edit, SAGE Publications Inc 2018).

Maysa S Bydoon OFA, "State Responsibility and COVID 19” (2019) 08 Journal of Arts \& Humanities.

Nano Prawoto, Eko Priyo Purnomo AAZ, “The Impacts of Covid-19 Pandemic on Socio-Economic Mobility in Indonesia” (2020) VIII International Journal of Economics and Business Administration.

Neuman WL, Social Research Methods: Qualitative and Quantitative Approaches, vol 30 (Seventh Ed, Pearson Custom Library 2002).

Nur Rohim Yunus AR, “Kebijakan Pemberlakuan Lock Down Sebagai Antisipasi Penyebaran Corona Virus Covid-19" (2020) 7 SALAM: Jurnal Sosial dan Budaya Syar-i.

Pratiwi RR, Nurlaily H and Artha D, "Analisa Yuridis Penetapan Covid 19 Sebagai Kedaruratan Kesehatan Masyarakat Ditinjau Dari Peraturan PerundangUndangan Di Indonesia" (2020) 1 Journal Inicio Legis $1<\mathrm{https} / /$ journal. trunojoyo.ac.id/iniciolegis/article/download/8827/4915>.

Rizal JG, "Mudik Dilarang Tapi Tempat Wisata Dibuka, Ini Penjelasan Satgas Penanganan Covid-19" (Kompas.com, 2021)<https:/www.kompas.com/tren/ $\mathrm{read} / 2021 / 04 / 23 / 201000865 /$ mudik-dilarang-tapi-tempat-wisata-dibuka-inipenjelasan-satgas-penanganan?page $=$ all $>$.

Sanyaolu A and others, "Global Pandemicity of COVID-19: Situation Report as of June 9, 2020" (2021) 14 Infectious Diseases: Research and Treatment $1178633721991260<\mathrm{https}: / /$ doi.org/10.1177/1178633721991260>.

Setyoningsih A and Artaria MD, "Pemilihan Penyembuhan Penyakit Melalui 
Pengobatan Tradisional Non Medis Atau Medis" (2016) 29 Masyarakat, Kebudayaan dan Politik.

Suhaedading LI, "Pembatasan Sosial Berskala Besar (PSSB) Saat Pandemi Covid-19 Dan Dampaknya Bagi Pasar Modal Indonesia" (2020) 2 Abiwara : Jurnal Vokasi Administrasi Bisnis.

van der Brug PH, "Malaria in Batavia in the 18th Century." (1997) 2 Tropical medicine \& international health : TM \& IH.

Walikota Makassar, "Peraturan Walikota Makassar Nomor 22 Tahun 2020 Tentang Pelaksanaan Pembatasan Sosial Berskala Besar (PSBB) Di Kota Makassar Provinsi Sulawesi Selatan".

Wei Y and others, "COVID-19 Prevention and Control in China: Grid Governance" (2021) 43 Journal of Public Health <https://doi.org/10.1093/pubmed/ fdaa175>.

Widyawati A and others, "Covid-19 and Human Rights: The Capture of the Fulfilment of Rights During the Covid Outbreaks" (2020) 6 Unnes Law 259 $<$ https://journal.unnes.ac.id/sju/index.php/ulj/article/view/42289>.

International Covenant on Civil and Political Rights (ICCPR) 1976.

Keputusan Gubernur Jakarta Nomor 107 Tahun 2021 tentang Pembatasan Kegiatan Masyarakat Berbasis Mikro (PPKM) 2021.

Keputusan Menteri Kesehatan Republik Indonesia Nomor 612/MENKES/ SK/V/2010 tentang Pedoman Penyelenggaraan Karantina Kesheatan pada Penanggulangan Kedaruratan Kesehatan Masyarakat yang Meresahkan Dunia 2010.

Undang-Undang Republik Indonesia Nomor24 Tahun 2007 Tentang Penanggulangan Bencana 2007.

Undang-Undang Republik Indonesia Nomor 39 Tahun 1999 Tentang Hak Asasi Manusia 1999.

HOW TO CITE: Syamsuddin Radjab and Muhammad Ikram Nur Fuady, 'The Indonesian Government's Inconsistency in Handling the Covid-19 Pandemic' (2021) 36 Yuridika. 